\title{
PENELITIAN TINDAKAN KELAS BERBASIS LESSON STUDY : MODEL THINK PAIRSHARE BERBANTUAN MEDIA KOMIK PROTISTA UNTUK MENINGKATKAN HASILBELAJAR BIOLOGI
}

\section{Classroom Action Research Based on Lesson Study : Think Pair Share Model with Comic of Protist to Improve the Result of Biology Learning}

\author{
Fadhlan Muchlas Abrori $^{\mathrm{a}^{*}}$, Yuni Krisnawati ${ }^{\mathrm{b}}$, Retna Ningsih $^{\mathrm{c}}$, Usman $^{\mathrm{d}}$ \\ a Program Studi Pendidikan Biologi, Universitas Borneo Tarakan, Tarakan, Kalimantan Utara \\ b Program Studi Pendidikan Biologi, STKIP PGRI Lubuklinggau, Lubuklinggau, Sumatera Selatan \\ c Program Studi Tadris Ilmu Pengetahuan Alam, UIN Sultan Syarif Kasim Riau, Riau \\ dTKS Kemnaker RI - Lombok, Nusa Tenggara Barat \\ ${ }^{*}$ Corresponding author: J1. Amal Lama, Tarakan Timur, Tarakan, Kalimantan Utara, 77123, Indonesia. E-mail: fadhlan1991 @ gmail.com
}

\section{Abstrak}

Tujuan dalam penelitian ini adalah untuk memecahkan permasalahan pada materi Protista melalui penerapan penelitian tindakan kelas (PTK) berbasis lesson study (LS). Penelitian menggunakan pendekatan kualitatif melalui penerapan PTK berbasis LS berbantuan media komik protista. Hal yang diamati dalam penelitian berupa persentase keterlaksanaan pembelajaran oleh guru dan siswa, serta hasil belajar siswa. Persentase keterlaksanaan pembelajaran oleh guru didapatkan kenaikan pada siklus satu sebesar 70,5\% dan siklus ke 4 sebesar 91,5\%. Senada dengan hal itu, pada persenase keterlaksanaan pembelajaran oleh siswa juga mengalami kenaikan dari siklus 1 sebesar 60,5\%, dan siklus ke 4 sebesar 90,5. Terkait hasil belajar didapatkan nilai baik pada siklus terakhir sebesar 76,75\% dengan standar deviasi sebesar 4,06, dan persentase ketuntasan sebesar $90 \%$.

\section{Kata kunci}

PTK, LS, Komik, Protista

\section{Abstract}

The aim of this research is to solve the problems in Protista Learning with implementation of Classroom Action Research (CAR) based on lesson study $(L S)$. This research used qualitative approach with CAR based on LS, and it used Protista Comic. There are 2 things that was observed was percentage of learning implementation (teacher and students), and students' learning outcome. Percentage of learning implementation by teacher showed the increase from $1^{\text {st }}$ cycle $(70.5 \%)$ to $4^{\text {th }}$ cycle $(91.5 \%)$. Similarly, the percentage of learning implementation by students showed the increase from $1^{\text {st }}$ cycle $(60.5 \%)$ to $4^{\text {th }}$ cycle $(90.5 \%)$. Then, Students' learning outcome provided the highest score at last cycle $76.75 \%$, and the deviation standart 4,06 , and the percentage of completeness $90 \%$.

Keywords: CAR, LS, Comic, Protista 


\section{Pendahuluan}

Guru sebagai orang yang memegang kendali sebagai fasilitator dalam proses pembelajaran perlu memenuhi kompetensi berdasarkan Undang-Undang Nomor 14 Tahun 2005 tentang guru dan dosen. Kompetensi tersebut terdiri dari kompetensi profesional, kopetensi pedagogik, kompetensi kepribadian, dan kompetensi sosial). Upaya yang dilakukan oleh pemerintah dengan menyelenggarakan kompetensi guru. Namun, upaya ini tidak terlalu signifikan meningkatkan kompetensi guru. Sabon (2017) menyatakan bahwa tidak ada perbedaan antara guru yang tersertifikasi dan belum tersertifikasi. Hasil Ujian Komptensi Guru (UKG) 2015 yang diselenggarakan Kemendikbud (2015) guru yang tersertifikasi memiliki selisih lebih rendah sebesar $0,1 \%$ dengan guru yang belum tersertifikasi (tingkat Sekolah Dasar). Sementara itu, untuk tingkat menengah lebih tinggi 3,5\%.

Hasil tersebut mencerminkan guru yang tersertifikasi masih belum bisa menjalankan tugasnya sebagai seorang guru yang kompeten. Hal ini terjadi karena di Indonesia perbaikan hanya berbasis pada hasil pembelajaran, dan kurang memperhatikan proses pembelajaran. Brook \& Brook (1993) menyatakan bahwa perbaikan dalam sebuah pendidikan idealnya dilakukan pada proses pembelajaran. Proses pembelajaran ini nantinya akan berpengaruh kepada hasil pembelajaran.

Salah satu cara perbaikan proses pembelajaran adalah melalui pelaksanaan Penelitian Tindakan Kelas (PTK). Sumini (2017) menyatakan bahwa PTK merupakan suatu bentuk penelitian yang bersifat reflektif, di mana refleksi memegang peranan penting dalam memperbaiki praktek-praktek pembelajaran di dalam kelas. Pada penerapannya PTK dapat dipadukan dengan lesson study (LS). Prihantoro (2011) menyatakanbahwalesson study mampu membantu guru dalam mengembangkan program-program pembelajaran yang efektif dan inovatif melalui pemanfaatan fasilitas belajar secara maksimal. Stiegler \& Hiebert (1999) juga menyatakan dalam LS guru melakukan pertemuan secara periodik dalam kegiatan implementasi, ujicoba dan pengembangan penelitian dalam pembelajaran.

Penerapan PTK berbasis LS dapat dibantu dengan penggunaan media yang inovatif dan efektif. Media yang digunakan adalah komik pembelajaran. Komik pembelajaran dikembangkan karena sifat dari komik yang mudah digunakan, karena konten dala sebuah materi disajikan dalam alur cerita (Abrori, 2014; Noer \& Abrori, 2018). Waluyanto (2006) juga menyatakan bahwa komik sebagai media visual mampu memberikan stimulus dalam pembelajaran. Seseorang akan melalui proses pembelajaran secara optimal apabila adanya interaksi yang sesuai antara stimulus yang diberikan dan gaya belajar/ kebiasaan belajar.

Penggunaan komik dalam penerapan PTK dilandaskan pada observasi yang dilakukan di MA Muhammadiyah 1 Malang terkait gaya belajar siswa kelas X. Hasil dari observasi didapatkan bahwa 91,2 \% siswa di kelas X memiliki gaya belajar visual. Hasil dari pengamatan proses pembelajaran juga didapatkan masih kurangnya proses kooperatif siswa, siswa cenderung hanya belajar satu arah. Apabila siswa dikelompokkan dalam sebuah kelompok, hanya beberapa siswa yang aktif, sementara sisanya kurang ikut berperan dalam kelompok. Pada observasi juga dianalisis materi yang memiliki tingkat ketuntasan atau nilai terendah selama 3 tahun berturut-turut, berdasarkan hasil observasi didapatkan materi Protista 


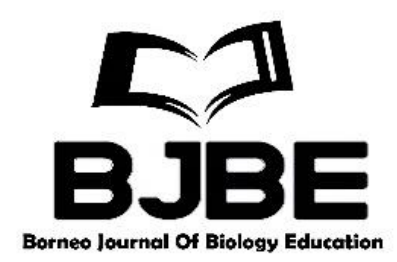

merupakan bab, dimana nilai rata-rata siswa hanya berkisar 62,1, dengan tingkat ketuntasan dibawah $60 \%$.

Berdasarkan hasil observasi maka ditetapkan model pembelajaran yang digunakan adalah Think Pair Share (TPS) yang dikembangkan oleh Lyman (1981). TPS dapat diartikan sebagai diskusi kolaboratif dimana individu diberikan kesempatan untuk berpikir terlebih dahulu sebelum berpasangan dengan teman sekelompoknya dan bertukar pikiran terkait hal atau topic yang diajukan (Lyman, 1981; Gunter et al., 1999).

Berdasarkan beberapa hal tersebut, maka akan dilaksanakan PTK berbasis LS melalui penerapan model pembelajaran TPS berbantuan media komik Protista. Dalam penelitian akan dilakukan beberapa evaluasi terutama terkait persentase keterlaksanaan pembelajaran dan hasil belajar siswa.

\section{Jenis Penelitian}

\section{Material dan metode}

Penelitian ini berupa penelitin kualitatif dengan menggunakan Penelitian Tindakan Kelas (PTK) berbasis lesson study yang mengacu kepada Susilo (2009). Pada awal guru model akan berkolaborasi dengan guru mitra di MA Muhammadiyah 1 Malang untuk menyusun perangkat pembelajaran berdasarkan hasil observasi yang dilakukan. Setelah pertemuan ke dua dan mendapatkan permasalahan lainnya selanjutnya dirancang PTK secara kolaboratif antara guru model dan guru mitra, hasil dari diskusi dilanjutkan kepada dosen di Universitas Negeri Malang sebagai pembimbing. Selanjutnya guru model dan guru mitra bersama lagi membuat perangkat berdasarkan hasil diskusi dan kosultasi (tahap plan PTK). Hasil dari tahap plan PTK didiskusikan dengan observer, guru lain dan dosen sebagai plan LS, dan disempurnakan berdasakan masukan pada diskusi.

RPP yang telah disempurnakan pada tahapan plan PTK dan plan LS, kemudian dilaksanakan dalam kegiatan do LS dan sekaligus tahapan action dan observation PTK. Setelah dilaksanak dilanjutkan tahapan reflect PTK dan kegiatan see LS sebagi dasar perbaikan pada pertemuan selanjutnya.

\section{Tempat dan Lokasi Penelitian}

Penelitian dilaksanakan di MA Muhammadiyah 1 Malang. Kelas yang digunakan adalah kelas $\mathrm{X}$ yang terdiri dari 20 orang siswa. Siklus PTK berbasis LS dilaksanakan sebanyak 4 siklus. Pelaksanaan dimulai pada tangal 16 September 2013 - 4 Oktober 2013. Jumlah Total keseluruhan anggota dalam penelitian ini melibatkan 1 orang guru model, 1 orang guru mitra, 1 orang dosen pembimbing dan 3 orang observer. Indikator ketercapaian dalam penelitian ini adalah jumlah ketuntasan siswa berdasarkan nilai KKM pada pelajaran Biologi kelas $X$ sebesar 75 dengan persentase > 85\%. Materi yang digunakan dalam penelitian ini adalah materi Protista pada semester ganjil kelas $\mathrm{X}$

\section{Analisis data}

Pada penelitian ini terdapat 2 data yang diukur, yaitu: data hasil belajar dan data keterlaksanaan Lesson Study. Data hasil belajar yaitu nilai tes tertulis di setiap akhir siklus. Data dianalisis dengan menghitung persentase ketuntasan klasikal. Data keterlaksanaan kegiatan diukur dengan menggunakan lembar obervasi keterlaksanaan pembelajaran. Data keterlaksanaan pembelajaran dianalisis dengan menghitung persentase keterlaksanaan kegiatan pembelajaran. 


\section{Hasil dan Diskusi}

Hal pertama yang diamati dalam penerapan PTK berbasis LS adalah keterlaksanaan pembelajaran baik oleh guru dan siswa. Untuk mengetahui keterlaksanaan pembelajaran indikatornya adalah keterlaksanaan tahapan pembelajaran yang tertuang dalam Rencana Pelaksanaan Pembelajaran. Hasil persentase keterlaksanaan pembelajaran disajikan pada Gambar 1.

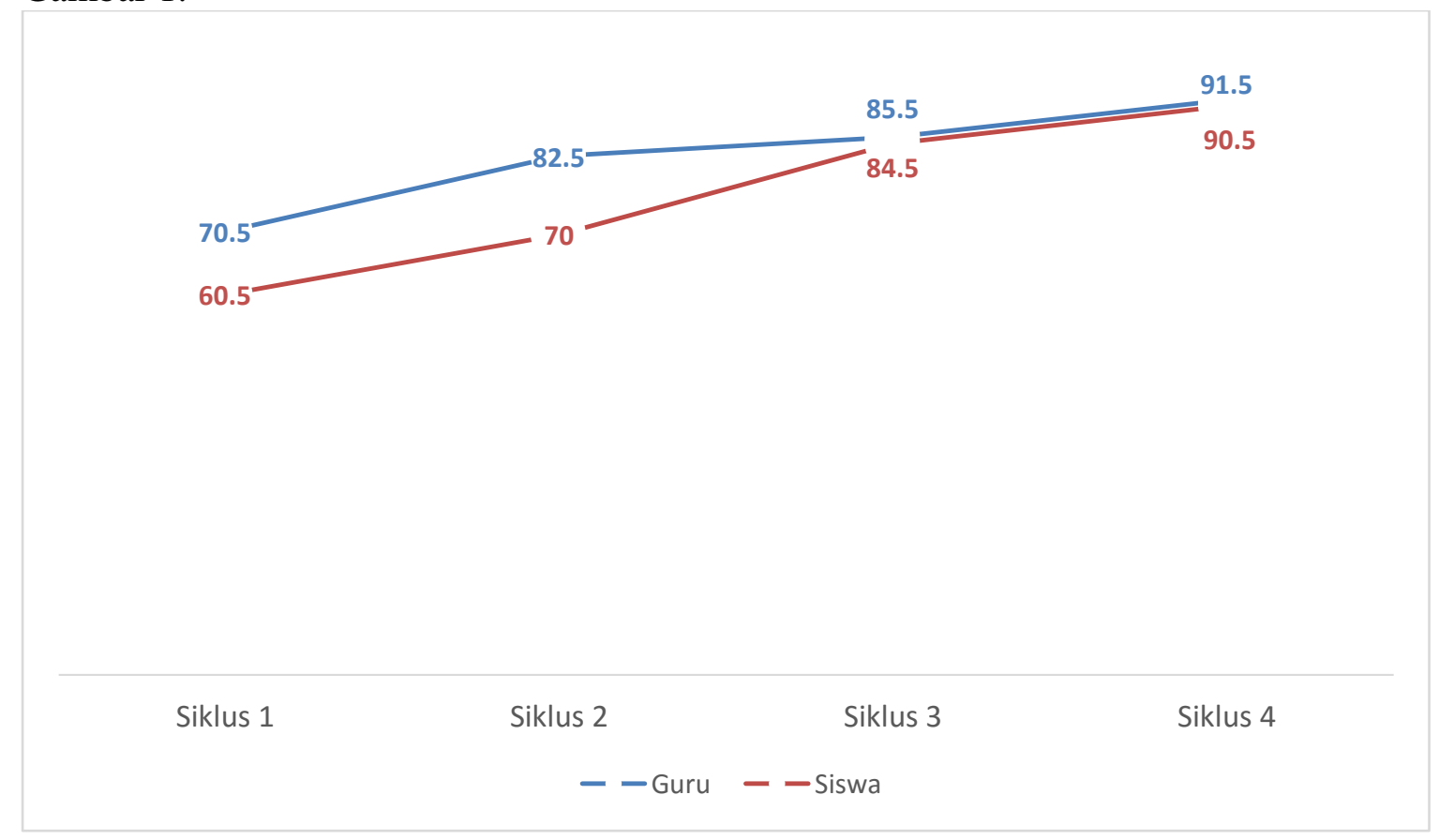

Gambar 1. Persentase Keterlaksanaan Pembelajaran oleh guru dan siswa

Pada grafik di atas terlihat peningkatan dari siklus pertama sampai siklus keempat. NIlai terendah didapatkan guru dan siswa pada awal siklus. Hal ini terjadi karena siswa masih beradaptasi dengan model TPS yang belum pernah digunakan sebelumnya dalam kelas, dampak dari belum terbiasanya siswa dalam mengikuti model ini alokasi yang digunakan oleh guru menjadi tidak seimbang. Hal ini berdampak pada keterlaksanaan pembelajaran oleh guru.

Pembiasaan TPS memang membutuhkan banyak waktu, karena membiasakan siswa untuk berpikir mandiri terlebih dahulu, kemudian berpasangan dengan temannya. Hasil di lapangan menunjukkan siswa yang pasif cukup susah menerapkan berpikir mandiri. Lie (2003) berpendapat bahwa TPS akan meningkatkan setidaknya 8 kali lipat partisipasi siswa dalam pembelajaran, dibandingkan model klasikal. Berdasarkan hal ini maka perlu penyesuaian yang sedikit lebih lama pada siswa yang belum terbiasa dengan model ini

Kesulitan di awal juga terlihat ketika siswa menggunakan media komik, siswa antusias dengan cerita komik. Namun, ketika siswa masuk ke dalam lembar diskusi dalam komik, mereka merasa kesulitan. Hal ini dikarenakan diskusi dalam komik menitik beratkan pada berpikir tingkat tinggi. Hal ini tentu menjadi permasalahan tersendiri bagi siswa yang belum terbiasa.Secara garis besar King et al. (1998) kemampuan berpikir tingkat tinggi memerlukan pemikiran kritis, logis, reflektif, metakognitif, dan kreatif. Sementara itu, Marshal \& Horton (2011) menyatakan berpikir tingkat tinggi juga memerlukan penalaran siswa untuk mengaitkan sebuah topik dalam kehidupan sehari-hari. Sudrajat (2011) 


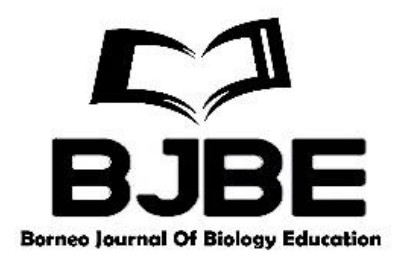

menambahkan penalaran membutuh kemampuan mengingat kembali (recall). Berdasarkan hasil observasi siswa di MA Muhammadiyah 1 Malang masih kesulitan untuk menerapkan hal ini pada siklus pertama. Namun pada siklus-siklus berikutnya siswa mulai terbiasa dengan diskusi pada komik pembelajaran.

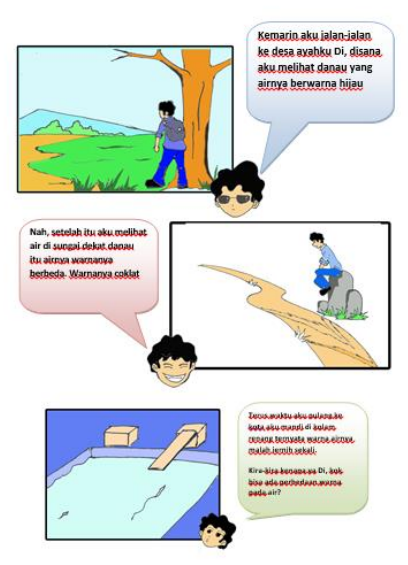

a

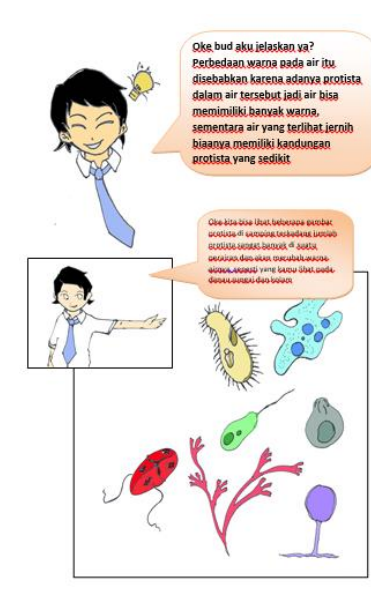

b

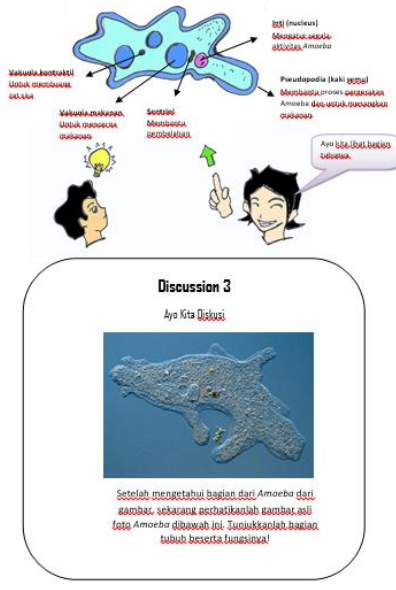

c

Gambar 2. Komik Pembelajaran: a) bagian pendahuluan; b) bagian materi inti; dan c) bagian diskusi

Perbaikan pada tiap tahapan melalui refleksi selalu dilakukan oleh guru model berdasarkan masukan dari guru mitra, dosen pembimbing dan observer. Masukan cukup beragam, misalkan memberikan panduan terlebih dahulu dalam bagian diskusi di komik melalui sebuah alur cerita tersendiri. Masukan juga pada penerapan TPS, dimana guru memberikan tugas membaca dulu terkait topik yang akan didiskusikan, sehingga siswa bisa fokus menjawab.

Masukan tersebut memberikan dampak peningkatan pada siklus selanjutnya, sehingga nilai akhir persentase keterlaksanaan pembelajaran mencapai angka di atas $90 \%$. Hal ini memberikan dampak juga pada hasil belajar siswa. Rincian rata-rata, standar deviasi dan persentase ketuntasan siswa tergambarkan pada Tabel 1.

Tabel 1. Hasil Belajar Siswa

\begin{tabular}{lllll}
\hline \multirow{2}{*}{ No } & \multicolumn{1}{c}{ Siklus Ke- } & \multicolumn{1}{c}{ Rata-Rata } & Standar Deviasi & \multicolumn{1}{c}{$\begin{array}{c}\text { Persentase } \\
\text { Ketuntasan }\end{array}$} \\
\hline 1 & Siklus 1 & 51.5 & 10.40 & $5 \%$ \\
2 & Siklus 2 & 60 & 7.07 & $10 \%$ \\
3 & Siklus 3 & 71.25 & 6.46 & $50 \%$ \\
4 & SIklus 4 & 76.75 & 4.06 & $90 \%$ \\
\hline
\end{tabular}

Berdasarkan tabel 1 didapatkan data terjadi peningkatan rata-rata pada setiap siklus. Sementara itu, standar deviasi semakin kecil. Hal ini menunjukkan nilai semakin baik dengan rentang antara nilai terendah dan tertinggi semakin kecil (ditandai dengan standar deviasi). Terkait persentase didapatkan persentase yang meningkat, siklus dilaksanakan sebanyak 4 kali karena persentase belum mencapai standar minimal sebesar 85\%. Persentase melebihi standar pada siklus ke-4 sehingga pelaksanaan pembelajaran pada materi Protista dikatakan tuntas 


\section{Kesimpulan}

Pada persentase keterlaksanaan pembelajaran oleh guru meningkat dari siklus ke 1 sebesar 70,5\% dan siklus ke 4 sebesar 91,5\%. Senada dengan hal itu, pada persenase keterlaksanaan pembelajaran oleh siswa juga mengalami kenaikan dari siklus 1 sebesar $60,5 \%$, dan siklus ke 4 sebesar 90,5. Terkait hasil belajar didapatkan nilai baik pada siklus terakhir sebesar 76,75 dengan standar deviasi sebesar 4,06, dan persentase ketuntasan sebesar $90 \%$.

\section{Daftar Pustaka}

Abrori, F. M. (2014). Analisis Taksimetri Tumbuhan Paku Suku Polypodiaceae di Daerah Cangar sebagai Buku Ajar Berbasis Komik untuk SMA. DISERTASI dan TESIS Program Pascasarjana UM.

Brooks, J. G., \& Brooks, M. G. 1993. In search of understanding: The case for constructivistclassrooms. Virginia: Association for Supervision and Curriculum Development.

Gunter, M. A., Estes, T. H., \& Schwab, J. H. (1999). Instruction: A Models Approach, 3rd edition. Boston: Allyn \& Bacon.

Kementerian Pendidikan dan Kebudayaan. 2015. Data Uji Kompetensi Guru 2012-2015. Jakarta:Direktorat Jenderal Guru dan Tenaga Kependidikan Kementerian Pendidikan danKebudayaan.

King, F. J., Goodson, L., \& Rohani, F. (1998). Higher order thinking skills: Definition, teaching strategies, assessment. Publication of the Educational Services Program, now known as the Center for Advancement of Learning and Assessment. Obtido de: www. cala.fsu. edu.

Lie, Anita. 2003. Cooperative learning Mempraktekan cooperative learning di ruang-ruang kelas.Jakarta: Gramedia Widiasana Indonesia.

Lyman, F. (1981). Strategies for Reading Comprehension Think Pair Share. Unpublished Paper. University of Maryland Paper. http://www. roel3. $\mathrm{kl}$. il. us/Services/KeriKorn/BDA/ThinkPairShare. Pdf. Diakses 12 Mei 2013

Marshall, J. C., \& Horton, R. M. (2011). The relationship of teacher- facilitated, inquirybased instruction to student higher- order thinking. School Science and Mathematics, 111(3), 93-101.

Noer, R. Z., \& Abrori, F. M. (2018). Pengembangan Komik Pembelajaran pada Materi Bumi dan Alam Semesta untuk Siswa Sekolah Dasar Kelas VI di SDN Utama 2 Tarakan dan SDN 17 Tarakan. Jurnal Bidang Pendidikan Dasar, 2(1A), 59-69.

Prihantoro, R. (2011). Pengembangan Profesionalisme Guru Melalui Model Lesson Study. Jurnal Pendidikan dan Kebudayaan, 17(1), 100-108.

Sabon, S. S. (2017). Persepsi Siswa Terhadap Kompetensi Guru Yang Sudah dan Belum Disertifikasi. Jurnal Pendidikan dan Kebudayaan, 2(1), 55-80

Stigler, J., \& Hiebert, J. (1999). The teaching gap: Best ideas from the world's teachers for improving education in the classroom. New York: Free Press.

Sudrajat, Akhmad. 2011. KemampuanMenganalisis Dalam Pembelajaran(Online). http://akhmadsudrajat.wordpress.com/. Diakses 13 Juni 2013

Sumini, T. (2017). Penelitian Tindakan Kelas dan Pengembangan Profesi Guru. Artikel Ilmiah. Universitas Sanata Dharma. Yogyakarta

Susilo, H. 2009. Penggabungan Lesson Study dan Penelitian Tindakan Kelas dalam Pemantapan Kemampuan Mengajar sebagai Upaya Memperkaya Pengalaman 


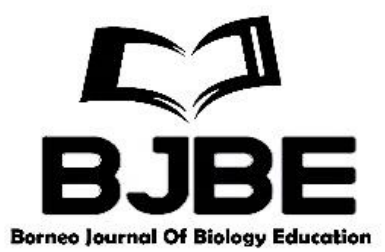

Mahasiswa Peserta Program Sertifikasi Guru dalam Jabatan melalui Jalur Pendidikan. Makalah disampaikan pada Workshop Pembimbingan dan Penilaian PKM Program Sertifikasi Guru Jalur Pendidikan oleh UPT PPL Universitas Negeri Malang pada 18 Maret 2009

Undang-Undang Nomor 14 Tahun 2005 tentang guru dan dosen.

Waluyanto, H. D. (2006). Komik sebagai media komunikasi visual pembelajaran. Nirmana, $7(1)$. 